\title{
Health justice in the Anthropocene: medical ethics and the Land Ethic
}

\author{
Alistair Wardrope (i) 1,2
}

${ }^{1}$ Academic Neurology Unit, The University of Sheffield, Sheffield, UK

${ }^{2}$ Department of Neurosciences, Sheffield Teaching Hospitals NHS Foundation Trust, Sheffield, UK

\section{Correspondence to}

Dr Alistair Wardrope, Academic Neurology Unit, The University of Sheffield, Sheffield S10 2TN UK;

ajwardrope1@sheffield.ac.uk

Received 29 August 2020

Accepted 1 September 2020

Published Online First

7 October 2020
Check for updates

(c) Author(s) (or their employer(s)) 2020. No commercial re-use. See rights and permissions. Published by BMJ.

To cite: Wardrope $A$.

$J$ Med Ethics

2020:46:791-796

\section{ABSTRACT}

Industrialisation, urbanisation and economic development have produced unprecedented (if unevenly distributed) improvements in human health. They have also produced unprecedented exploitation of Earth's life support systems, moving the planet into a new geological epoch, the Anthropocene - one defined by human influence on natural systems. The health sector has been complicit in this influence. Bioethics, too, must acknowledge its role- - the environmental threats that will shape human health in this century represent a 'perfect moral storm' challenging the ethical theories of the last. The US conservationist Aldo Leopold saw this gathering storm more clearly than many, and in his Land Ethic describes the beginnings of a route to safe passage. Its starting point is a reinterpretation of the ethical relationship between humanity and the 'land community', the ecosystems we live within and depend upon; moving us from 'conqueror' to 'plain member and citizen' of that community. The justice of the Land Ethic questions many presuppositions implicit to discussions of the topic in biomedical ethics. By valuing the community in itself-in a way irreducible to the welfare of its members-it steps away from the individualism axiomatic in contemporary bioethics. Viewing ourselves as citizens of the land community also extends the moral horizons of healthcare from a solely human focus. Taking into account the 'stability' of the community requires intergenerational justice. The resulting vision of justice in healthcare - one that takes climate and environmental justice seriously — could offer health workers an ethic fit for the future.

\section{INTRODUCTION}

It did not occur to the Governor that there might be more than one definition of what is good ... It did not occur to him that while the courts were writing one definition of goodness in the law books, fires were writing quite another one on the face of the land. (Leopold, 'Good Oak', pp 10-11)

As I wrote the abstract that would become this essay, wildfires were spreading across Australia's east coast. By the time I was invited to write the essay, back-to-back winter storms were flooding communities all around my home. The essay has been written in moments of respite between shifts during the COVID-19 pandemic. Every one of these events was described as 'unprecedented'; yet each is becoming increasingly likely, and that due to our interactions with our environment.

Public discourse surrounding these events is dominated by questions of justice and fairness: how to balance competing imperatives of protecting individual lives against risk of spreading contagion; how best to allocate scarce resources like intensive care beds or mechanical ventilators. The conceptual tools of clinical ethics are well tailored to these sorts of questions: the rights of the individual versus the community, issues of distributive justice-these are familiar to anyone with even a passing acquaintance with its canonical debates.

What biomedical ethics has remained largely silent on is how we have been left to confront these decisions. How human activity has eroded Earth's life support systems to make the 'unprecedented' the new normal. A medical ethic fit for the Anthropocene-our (still tentative) geological epoch defined by human influence on natural systemsmust be able not just to react to the consequences of our exploitation of the natural world, but reimagine our relationship with it.

Those reimaginations already exist, if we know where to look for them. The 'Land Ethic' of the US conservationist Aldo Leopold offers one such vision. ${ }^{i}$ Developed over decades of experience working in and teaching land management, the Land Ethic is most famously formulated in an essay of the same name published shortly before Leopold's death fighting a wildfire on a neighbour's farm. It begins with a reinterpretation of the ethical relationship between humanity and the 'land community', the ecosystems we live within and depend upon; moving us from 'conqueror' to 'plain member and citizen' of that community ${ }^{1}(p$ 204). Land ceases to be a resource to be exploited for human need once we view ourselves as part of, and only existing within, the land community. Our moral evaluations shift consonantly:

A thing is right when it tends to preserve the integrity, stability, and beauty of the biotic community. It is wrong when it tends otherwise. ${ }^{1}(\mathrm{pp} 224-225)$

${ }^{\mathrm{i}}$ It is important to acknowledge from the outset that, considered globally, Leopold's work is not the first or only such reimagination. There is an irony in writing an essay on justice that centres the work of a North American white man over that of the Indigenous communities some claim inspired his work (there is a particular debate over the overlap between the Land Ethic and certain Indigenous American philosophies, particularly Anishinaabe ethics). I have found the work of Kyle Whyte and Robin Wall Kimmerer particularly useful in exploring these similarities and dissonances. ${ }^{22} 2.3$ However, I believe there is a particular value in the Land Ethic for understanding justice in Anthropocene healthcare. Leopold specifically addresses the Land Ethic as a development upon the worldview implicit in contemporary bioethics, highlighting its shortcomings and offering a way forward. Leopold's project of progressing in the 'ethical sequence' is distinct from-though perhaps complementary tothat of decolonising bioethics. The latter project is one I am better positioned to listen to and learn from than contribute to. ${ }^{2425}$ 
The justice of the Land Ethic questions many presuppositions of biomedical ethics. By valuing the community in itself-in a way irreducible to the welfare of its members-it steps away from the individualism axiomatic in contemporary bioethics. ${ }^{2}$ Viewing ourselves as citizens of the land community also extends the moral horizons of healthcare from a solely human focus, taking seriously the interests of the non-human members of that community. Taking into account the 'stability' of the community requires intergenerational justice-that we consider those affected by our actions now, and their implications for future generations. ${ }^{3}$ The resulting vision of justice in healthcare-one that takes climate and environmental justice seriously-could offer health workers an ethic fit for the future, demonstrating ways in which practice must change to do justice to patients, public and planet-now and in years to come.

\section{HEALTHCARE IN THE ANTHROPOCENE}

Seemeth it a small thing unto you to have fed upon good pasture, but ye must tread down with your feet the residue of your pasture? And to have drunk of the clear waters, but ye must foul the residue with your feet? (Ezekiel 34:18, quoted in Leopold, 'Conservation in the Southwest ${ }^{4}, \mathrm{p}$ 94)

The majority of the development of human societies worldwide-including all of recorded human history-has taken place within a single geological epoch, a roughly 11600 yearlong period of relative warmth and climatic stability known as the Holocene. That stability, however, can no longer be taken for granted. The epoch that has sustained most of human development is giving way to one shaped by the planetary consequences of that development-the Anthropocene.

The Anthropocene is marked by accelerating degradation of the ecosystems that have sustained human societies. Human activity is already estimated to have raised global temperatures $1^{\circ} \mathrm{C}$ above preindustrial levels, and if emissions continue at current levels we are likely to reach $1.5^{\circ} \mathrm{C}$ between 2030 and 2052..$^{5}$ The global rate of species extinction is orders of magnitude higher than the average over the past 10 million years. ${ }^{6}$ Ocean acidification, deforestation and disruption of nitrogen and phosphorus flows are likely at or beyond sustainable planetary boundaries. ${ }^{7}$

Yet this period has also seen rapid (if uneven) improvements in human health, with improved life expectancy, falling child mortality and falling numbers of people living in extreme poverty. The 2015 report of the Rockefeller Foundation-Lancet Commission on planetary health explained this dissonance in stark terms: 'we have been mortgaging the health of future generations to realise economic and development gains in the present. $^{7}$

In the instrumental rationality of modernity, nature has featured only as inexhaustible resource and infinite sink to fuel social and economic ends. But this disenchanted worldview can no longer hide from the implausibility of these assumptions; it cannot resist what the philosopher Isabelle Stengers has called 'the intrusion of Gaia'. ${ }^{8}$ The present pandemic-made more likely by deforestation, land use change and biodiversity loss ${ }^{9}-$ is just the most immediately salient of these intrusions. Anthropogenic environmental changes are increasing undernutrition, increasing range and transmissibility of many vectorborne and waterborne diseases like dengue fever and cholera, increasing frequency and severity of extreme weather events like heatwaves and wildfires, and driving population exposure to air pollutionwhich already accounts for over 7 million deaths annually. ${ }^{10}$
These intrusions will shape healthcare in the Anthropocene. This is because health workers will have to deal with their consequences, and because modern industrialised healthcare as practised in most high-income countries-and considered aspirational elsewhere-was borne of the same worldview that has mortgaged the health of future generations. The health sector in the USA is estimated to account for $8 \%$ of the country's greenhouse gas footprint. ${ }^{11}$ Pharmaceutical production and waste causes more local environmental degradation, accumulating in water supplies with damaging effects for local flora and fauna. ${ }^{12}$ Public health has similarly embraced short-term gains with neglect of long-term consequences. Health messaging was instrumental to the development and popularisation of many disposable and single-use products, while a 1947 report funded by the Rockefeller Foundation (who would later fund the landmark 2015 Lancet report on planetary health) popularised the high-meat, high-dairy 'American' diet-dependent on fossil fueldriven intensive agricultural practices-as the healthy ideal. ${ }^{13}$

Healthcare fit for the Anthropocene requires a shift in perspectives that allows us to see and work with the intrusion of Gaia. But can dominant approaches in bioethics incorporate that shift?

\section{A PERFECT MORAL STORM}

We have built a beautiful piece of social machinery ... which is coughing along on two cylinders because we have been too timid, and too anxious for quick success, to tell the farmer the true magnitude of his obligations. (Leopold, 'The Ecological Conscience ${ }^{4}, \mathrm{p} 341$ )

At local, national and international scales, the lifestyles of the wealthiest pose an existential threat to the poorest and most marginalised in society. Our actions now are depriving future generations of the environmental prerequisites of good health and social flourishing. If justice means, as Ranaan Gillon parses it, 'the moral obligation to act on the basis of fair adjudication between competing claims', ${ }^{14}$ then this state of affairs certainly seems unjust. However, the tools available for grappling with questions of justice in bioethics seem ill equipped to deal with these sorts of injustice.

To illustrate this problem, consider how Gillon further fleshes out his description of justice: in terms of fair distribution of scarce resources, respect for people's rights, and respect for morally acceptable laws. The first of these-labelled distributive justice-concerns how fairly to allot finite resources among potential beneficiaries. Classic problems of distributive justice in healthcare concern a group of people at a particular time (usually patients), who could each benefit from a particular resource (historically, discussions have often focused on transplant organs; more recently, intensive care beds and ventilators have come to the fore); but there are fewer of these resources than there are people with a need for them. Such discussions are not easy, but they are at least familiar-we know where to begin with them. We can consider each party's need, their potential to benefit from the resource, any special rights or other claims they may have to it, and so forth. The distribution of benefits and harms in the Anthropocene, however, does not comfortably fit this formalism. It is one thing to say that there is but one intensive care bed, from which Smith has a good chance of gaining another year of life, Jones a poor chance, and so offer it to Smith; another entirely to say that production of the materials consumed in Smith's care has contributed to the degradation of scarce water supplies on the other side of the globe, or that the unsustainable pattern of energy use will affect innumerable other future persons in poorly quantifiable ways through fuelling 
climate change. The calculations of distributive justice are well suited to problems where there are a set pool of potential beneficiaries, and the use of the scarce resources available affects only those within that pool. But global environmental problems do not fit this pattern - the effects of our actions are spatially and temporally dispersed, so that large numbers of present and future people are affected in different ways.

Nor can this problem be readily addressed by turning to Gillon's second category of obligations of justice, those grounded in human rights. For while it might be plausible (if not entirely uncontroversial) to say that those communities whose water supplies are degraded by pharmaceutical production have a right to clean water, it is another thing entirely to say that Smith's healthcare is directly violating that right. It would not be true to say that, were it not for the resources used in caring for Smith, that the communities in question would face no threat to water security-indeed, they would likely make no appreciable difference. Similarly for the effects of Smith's care on future generations facing accelerating environmental change. ${ }^{\text {ii }}$

The issue here is of fragmentation of agency. While it is not the case that Smith's care is directly responsible for these environmental harms, the cumulative consequences of many such actsand the ways in which these acts are embedded in particular systems of energy generation, waste management, international trade, and so on-are reliably producing these harms. The injustice is structural, in Iris Marion Young's terminology—arising from the ways in which social structures constrain individuals from pursuing certain courses of action, and enable them to follow others, with side effects that cumulatively produce devastating impacts. ${ }^{15}$

Gillon describes the third component of justice as respect for morally acceptable laws. But there is little reason to believe that existing legal frameworks provide sufficient guidance to address these structural injustices. While the intricacies of global governance are well beyond what I can hope to address here, the stark fact remains that, despite the international commitment of the 2015 Paris Agreement to attempt to keep global temperature rise to $1.5^{\circ} \mathrm{C}$ above preindustrial levels, the Intergovernmental Panel on Climate Change estimates that present national commitments-even if these are substantially increased in coming years-will take us well beyond that target. ${ }^{5}$ Confronted by such institutional inadequacy, respect for the rule of law is inadequate to remedy injustice.

The confluence of these particular features-dispersion of causes and effects, fragmentation of agency and institutional inadequacy-makes it difficult for us to reason ethically about the choices we have to make. Stephen Gardiner calls this a 'perfect moral storm'. ${ }^{16}$ Each of these factors individually would be difficult to address using the resources of contemporary biomedical ethics; their convergence makes it seem insurmountable.

This perfect storm was not, however, unpredictable. Van Rensselaer Potter, a professor of Oncology responsible for introducing the term 'bioethics' into Anglophone discourse, observed that since he coined the phrase, the study of bioethics had diverged from his original usage (governing all issues at the intersection of ethics and the biological sciences) to a narrow focus on the moral dilemmas arising in interactions between individuals in biomedical contexts. Potter predicted that the short-term, individualistic and medicalised focus of this approach would result in

\footnotetext{
${ }^{\mathrm{ii}}$ In fact, the problem here is even worse because it is not even clear to whom we would be assigning rights-these are not existing people or communities, put an ill-defined number of potential future people.
}

a neglect of population-level and ecological-level issues affecting human and planetary health, with catastrophic consequences. ${ }^{17}$ His proposed solution was a new 'global bioethics', grounded in a new understanding of humanity's position within planetary systems—one articulated by the Land Ethic.

\section{THE LAND ETHIC}

A land ethic changes the role of Homo sapiens from conqueror of the land-community to plain member and citizen of it. It implies respect for his fellow-members, and also respect for the community as such. ${ }^{\text {iii }}$ (Leopold, 'The Land Ethic', p 204)

Developed throughout a career in forestry, conservation and wildlife management, the Land Ethic is less an attempt to provide a set of maxims for moral action, than to shift our perspectives of the moral landscape. In his working life, Aldo Leopold witnessed how actions intended to optimise short-term economic outcomes eroded the environments on which we depend-whether soil degradation arising from intensive farming and deforestation, or disruption of freshwater ecosystems by industrial dairy farming. He also saw that contemporary morality remained silent on such actions, even when their consequences were to the collective detriment of all.

Leopold argued that a series of 'historical accidents' left our morality particularly ill suited to handle these intrusions of Gaia-with a worldview that considered them 'intrusions', rather than the predictable response of our biotic community. These 'accidents' were: the unusual resilience of European ecological communities to anthropogenic interference (England survived an almost wholesale deforestation without consequent loss of ecosystem resilience, while similar changes elsewhere resulted in permanent environmental degradation); and the legacy of European settler colonialism, meaning that an ethic arising in these particular conditions came to dominate global social arrangements ${ }^{4}$ (p 311). The first of these supported a worldview in which 'Land ... is ... something to be tamed rather than something to be understood, loved, and lived with. Resources are still regarded as separate entities, indeed, as commodities, rather than as our cohabitants in the land community ${ }^{4}$ ( $p$ 311). The second enabled the marginalisation of other views. In this genealogy, Leopold anticipated the perfect moral storm discussed above; his intent with the Land Ethic was to navigate it.

There are three key components of the Land Ethic that comprise the first three sections of Leopold's final essay on the subject: (1) the 'community concept' that allows communities as wholes to have intrinsic value; (2) the 'ethical sequence' that situates the value of such communities as extending, not replacing, values assigned to individuals; and (3) the 'ecological conscience' that views ethical action not in terms of following a particular code, but in developing appropriate moral perception.

\section{The community concept}

The most widely quoted passage of Leopold's opus-already cited above, and frequently (mis)taken as a summary maxim of the ethic-states that:

A thing is right when it tends to preserve the integrity, stability, and beauty of the biotic community. It is wrong when it tends otherwise. ${ }^{1}$ (pp 224-225)

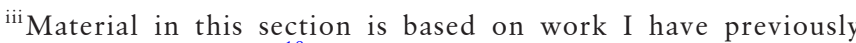
published elsewhere. ${ }^{18}$
} 
This passage makes the primary object of our moral responsibilities 'the biotic community', a term Leopold uses interchangeably with the 'land community'. Leopold's community concept is notable in at least three respects: its holism-an embrace of the moral significance of communities in a way that is not simply reducible to the significance of its individual members; its understanding of communities as temporally extended, placing importance on their 'integrity' and 'stability'; and its rejection of anthropocentrism, affording humanity a place as 'plain member and citizen' of a broader land community.

Individualism is so prevalent in biomedical ethics that it is scarcely argued for, instead forming part of the 'background constellation of values' ${ }^{2}$ tacitly assumed within the field. We are used to evaluating the well-being of a community as a function of the well-being of its individual members-this is the rationale underlying quality-adjusted life year calculations endemic within health economics, and most discussions of distributive justice adopt some variation of this approach. Holism instead proposes that this makes no more sense than evaluating a person's wellbeing as an aggregate of the well-being of their individual organs. While we can sensibly talk about people's hearts, livers or kidneys, their health is defined in terms of and constitutively dependent on the health of the person as a whole. Similarly, holism proposes, while individuals can be identified separately, it only makes sense to talk about them and their well-being in the context of the larger biotic community which supports and defines us.

Holism helps us to negotiate the issues that confront individualistic accounts of collective well-being in Anthropocene health injustices. In the previous section, we found in the environmental consequences of industrialised healthcare that it is difficult to identify which parties in particular are harmed, and how much each individual action contributes to those harms. But our intuition that the overall result is unfair or unjust is itself a holistic assessment of the overall outcome, not dependent on our calculation of the welfare of every party involved. Holism respects the intuition that says—no matter the individuals involved—a world where people now exploit ecological resources in a fashion that deprives people in the future of the prerequisites of survival, is worse than one where communities now and in the future live in a sustainable relationship with their environment.

The second aspect of Leopold's community concept is that the community is something that does not exist at a single time and place-it is defined in terms of its development through time. Promoting the 'integrity' and 'stability' of the community requires that we not just consider its immediate interests, but how that will affect its long-term sustainability or resilience. We saw earlier the difficulties in trying to say just who is harmed and how when we approach harm to future generations individualistically. But from the perspective of the Land Ethic, when we exploit environmental resources in ways that will have predictable damaging results for future generations, the object of our harm is not just some purely notional future person. It is a presently existing, temporally extended entity-the community of which they will be part.

Lastly, Leopold's community is quite consciously a biotic-not merely human—community. Leopold defines the land community as the open network of energy and mineral exchange that sustains all aspects of that network:

Land... is not merely soil; it is a fountain of energy flowing through a circuit of soils, plants, and animals. Food chains are the living channels which conduct energy upward; death and decay return it to the soil. The circuit is not closed; some energy is dissipated in decay, some is added by absorption, some is stored in soils, peats, and forests, but it is a sustained circuit, like a slowly augmented revolving fund of life. ${ }^{4}$ (pp 268-269)

While the components within this network may change, the land community as a whole remains stable when the overall complexity of the network is not disrupted-other components are able to adjust to these changes, or new ones arise to take their place. ${ }^{\text {iv }}$

The normative inference Leopold makes from his understanding of the land community is this: it makes no sense to single out individual entities within the community as being especially valuable or useful, without taking into account the whole community upon which they mutually depend. To do so is self-defeating: by privileging the interests of a few members of the community, we ultimately undermine the prerequisites of their existence.

\section{The ethical sequence}

The Land Ethic's holism is in fact its most frequently critiqued feature. Its emphasis on the value of the biotic community leads some to allege a subjugation of individual interests to the needs of the environment. This critique neglects how Leopold positions the Land Ethic in what he calls the 'ethical sequence'. This is the gradual extension of scope of ethical considerations, both in terms of the complexity of social interactions they cover (from interactions between two people, to the structure of progressively larger social groups), and in the kinds of person they acknowledge as worthy of moral consideration (as we resist, for example, classist, sexist or racist exclusions from personhood).

This sequence serves less as a description of the history of morality, than a prescription for how we should understand the Land Ethic as adding to, rather than supplanting, our responsibilities to others. We do not argue that taking seriously health workers' responsibilities for public health and health promotion supplants their duties to the patients they work with on a daily basis; similarly, the Land Ethic implies 'respect for [our] fellow members, and also respect for the community as such, (p 204). At times, our responsibilities towards these different parties may come into tension; but balancing these responsibilities has always been part of the work of clinical ethics.

\section{The ecological conscience}

If the community concept gives a definition of the good, and the ethical sequence situates this definition within the existing moral landscape, neither offers an explicit decision procedure to guide right action. In arguing for the 'ecological conscience', Leopold explains his rationale for not attempting to articulate such a procedure. In his career as conservationist, Leopold witnessed time and again laws nominally introduced in the name of environmental protection that did little to achieve their long-term goals, while exacerbating other environmental threats. ${ }^{\mathrm{V}}$ This is not surprising, given the 'perfect moral storm' of Anthropocene global health and environmental threats discussed above; the cumulative results of apparently innocent actions can be widespread and damaging.

\footnotetext{
${ }^{\text {iv }}$ Leopold contrasts the slow and local changes in land communities wrought, for example, by forest fires to anthropogenic changes of 'unprecedented violence, rapidity and scope' that deplete the community of its ability to adapt to these perturbations ${ }^{4}$ (p 269).

${ }^{v} \mathrm{He}$ discusses some of these in depth in his essay on 'The Ecological Conscience'. 4
} 
Leopold's response to this problem is to advocate the cultivation of an 'ecological conscience'. What is needed to promote a healthy human relationship with the land community is not for us to be told exactly how and how not to act in the face of environmental health threats, but rather to shift our view of the land from 'a commodity belonging to us' towards 'a community to which we belong' ${ }^{1}$ ( $\mathrm{p}$ viii). To understand what the Land Ethic requires of us, therefore, we should learn more about the land community and our relationship with it, to develop our moral perception and extend its scope to embrace the non-human members of our community.

Seen in this light, the Land Ethic shares much in common with virtue ethics, where right action is defined in terms of what the moral agent would do, rather than vice versa. But rather than the Eudaimonia of individual human flourishing proposed by Aristotle, the phronimos of the Land Ethic sees their telos coming from their position within the land community. While clinical virtue ethicists have traditionally taken the virtues of medical practice to be grounded in the interaction with individual patients, the realities of healthcare in the Anthropocene mean that limiting our moral perceptions in this way would ultimately be self-defeating-hurting those very patients we mean to serve (and many more besides). ${ }^{18}$ The virtuous clinician must adopt a view of the moral world that can focus on a person both as an individual, and simultaneously as member of the land community. I will close by exploring how adopting that perspective might change our practice.

\section{JUSTICE IN THE ANTHROPOCENE}

Failing this, it seems to me we fail in the ultimate test of our vaunted superiority-the self-control of environment. We fall back into the biological category of the potato bug which exterminated the potato, and thereby exterminated itself. (Leopold, 'The River of the Mother of God'4, p 127)

I have articulated some of the challenges healthcare faces in the Anthropocene. I have suggested that the tools presently available to clinical ethics may be inadequate to meet them. The Land Ethic invites us to reimagine our position in and relationship with the land community. I want to close by suggesting how the development of an ecological conscience might support a transition to more just healthcare. I will not endeavour to give detailed prescriptions for action, given Leopold's warnings about the limitations of such codifications. Rather, I will attempt to show how the cultivation of an ecological conscience might change our perception of what justice demands. Following the tradition of virtue ethics with which the Land Ethic holds much in common, this is best achieved by looking at models of virtuous action, and exploring what makes it virtuous. ${ }^{19}$

Industrialised healthcare developed within a paradigm that saw the environment as inert resource and held that the scope of clinical ethics ranged only over the clinician's interaction with their patients. When we begin to see clinician and patient not as standing apart from the environment, but as 'member and citizen of the land community', their relationship with one another and with the world around them changes consonantly. The present pandemic has only begun to make commonplace the idea that health workers do not simply treat infectious diseases, but interact with them in a range of ways, including as vectorand as a result our moral obligations in confronting them may extend beyond the immediate clinical encounter, to cover all the other ways we may contract or spread disease. But we may be responsible for disease outbreaks with conditions other than COVID-19, and in ways beyond simply becoming infected. The development of an ecological conscience would show how our practices of consumption may fuel deforestation that accelerates the emergence of novel pathogens, or support intensive animal rearing that drives antibiotic resistance. ${ }^{18}$

The Land Ethic also challenges us not to abstract our work away from the places in which it takes place. General practitioner surgeries and hospitals are situated within social and land communities alike, shaping and shaped by them. These spaces can be used in ways that support or undermine those communities. Surgeries can work to empower their communities to pursue more sustainable and healthy diets by doubling as food cooperatives, or providing resources and 'social prescriptions' for increased walking and cycling. Hospitals can use their extensive real estate to provide publicly accessible green and wild spaces within urban environments, and use their role as major nodes in transport infrastructure to change that infrastructure to support active travel alternatives. ${ }^{\mathrm{vi}}$

The Land Ethic reminds us that a community (human or land) is not healthy if its flourishing cannot be sustainably maintained; an essential component of Anthropocene health justice is intergenerational justice. Contemporary industrialised healthcare has an unsustainable ecological footprint; continuing with such a model of care would serve only to mortgage the health of future generations for the sake of those living now. Ecologically conscious practice must take seriously the sorts of downstream, distributed consequences of activity that produce anthropogenic global health threats, and evaluate to what extent our most intensive healthcare practices truly serve to promote public and planetary health. It is not enough for the clinician to assume that our resource usage is a necessary evil in the pursuit of best clinical outcomes, for it is already apparent that much of our environmental exploitation is of minimal or even negative long-term value. The work of the National Health Service (NHS) Sustainable Development Unit has seen a $10 \%$ reduction in greenhouse gas emissions in the NHS from 2007 to 2015 despite an 18\% increase in clinical activity, ${ }^{20}$ while different models of care used in less industrialised nations manage to provide high-quality health outcomes in less resource-intensive fashion. ${ }^{21}$

\section{CONCLUSION}

Our present problem is one of attitudes and implements. We are remodelling the Alhambra with a steam-shovel. We shall hardly relinquish the steam-shovel, which after all has many good points, but we are in need of gentler and more objective criteria for its successful use. (Leopold, 'The Land Ethic'1, p 226)

The moral challenges of the Anthropocene do not solely confront health workers; but the potentially catastrophic health effects of anthropogenic global environmental change, and the contribution of healthcare activity to driving these changes provide a specific and unique imperative for action from health workers.

Yet it is hard to articulate this imperative in the language of contemporary clinical ethics, ill equipped for this intrusion of Gaia. Justice in the Anthropocene requires us to be able to adopt a perspective from which these changes no longer appear as unexpected intrusions, but that acknowledges the land community as part of our moral community. The Land Ethic articulates an understanding of justice that is holistic, structural,

\footnotetext{
${ }^{v i}$ Just some examples that go towards embodying what forms ecologically conscious clinical practice might take can be found in groups like the Lambeth GP Food Co-operative, South Yorkshire's Greener Practice group, the work of the Centre for Sustainable Healthcare, and in the NHS Forest project.
} 
intergenerational, and rejects anthropocentrism. This understanding seeks not to supplant, but to augment, our existing one. It aims to do so by helping us to develop an 'ecological conscience', seeing ourselves as 'plain member and citizen' of the land community. The Land Ethic does not provide a step-bystep guide to just action; nor does it definitively adjudicate on how to balance the interests of our patients, other populations now and in the future, and the planet. It could, however, help us on the first step towards that change-showing how to cultivate the 'internal change in our intellectual emphasis, loyalties, affections, and convictions ${ }^{1}$ (pp 209-210) necessary to realise the virtues of just healthcare in the Anthropocene.

Twitter Alistair Wardrope @a_wardrope

Acknowledgements This essay was written as a submission for the BMA Presidential Essay Prize. I am grateful to the organisers and judging panel for the opportunity.

Contributors AW is the sole author of this manuscript.

Funding The authors have not declared a specific grant for this research from any funding agency in the public, commercial or not-for-profit sectors.

Competing interests None declared.

Patient consent for publication Not required.

Provenance and peer review Not commissioned; internally peer reviewed.

Data availability statement There are no data in this work.

\section{ORCID iD}

Alistair Wardrope http://orcid.org/0000-0003-3614-6346

\section{REFERENCES}

1 Leopold A. A sand County Almanac and Sketches here and there. Oxford: Oxford University Press, 1949.

2 Callahan D. Individual good and common good: a communitarian approach to bioethics. Perspect Biol Med 2003;46(4):496-507.

3 Wardrope A. Intergenerational and social justice: there is more to environmental justice than accountability for Reasonableness. Am J Bioeth 2018;18(3):51-3.

4 Leopold A. The river of the mother of God: and other essays by Aldo Leopold. Madison, WI: University of Wiscons, 1991
5 IPCC. "Summary for Policymakers," in lobal Warming of $1.5^{\circ} \mathrm{C}$. An IPCC Special Report on the impacts of global warming of $1.5^{\circ} \mathrm{C}$ above pre-industrial levels and related global greenhouse gas emission pathways, in the context of strengthening the global response to the threat of climate change, sustainable development, and efforts to eradicate poverty. Geneva: World Meteorological Organisation, 2018.

6 IBPES. Global assessment report on biodiversity and ecosystem services of the Intergovernmental Science-Policy platform on biodiversity and ecosystem services. Bonn: Intergovernmental Science-Policy Platform on Biodiversity and Ecosystem Services, 2019.

7 Whitmee S, Haines A, Beyrer C, et al. Safeguarding human health in the Anthropocene epoch: report of the Rockefeller Foundation-Lancet Commission on planetary health. Lancet 2015;386(10007):1973-2028.

8 Stengers I. In catastrophic times: resisting the coming barbarism. Open Humanities Press, 2015.

9 Johnson CK, Hitchens PL, Pandit PS, et al. Global shifts in mammalian population trends reveal key predictors of virus spillover risk. Proc Biol Sci 2020;287(1924).

10 Watts N, Amann M, Arnell N, et al. The 2019 report of the Lancet countdown on health and climate change: ensuring that the health of a child born today is not defined by a changing climate. Lancet 2019;394(10211):1836-78.

11 Chung JW, Meltzer DO. Estimate of the carbon footprint of the US health care sector. JAMA 2009;302(18):1970-2.

12 Al Aukidy M, Verlicchi P, Voulvoulis N. A framework for the assessment of the environmental risk posed by pharmaceuticals originating from hospital effluents. SCi Total Environ 2014;493:54-64.

13 Bonneuil C, Fressoz J-B. The shock of the Anthropocene: the earth, history and US, Reprint edition. London New York, NY: Verso, 2017.

14 Gillon R. Medical ethics: four principles plus attention to scope. BMJ 1994;309(6948):184.

15 Young IM. Responsibility for justice. Oxford: Oxford University Press, 2011.

16 Gardiner SM. A perfect moral storm: climate change, intergenerational ethics and the problem of moral corruption. Environ Values 2006;15(3):397-413.

17 Potter VR. Global bioethics: building on the Leopold legacy. East Lansing, MI: Michigan State University Press, 1988.

18 Wardrope A. Does clinical ethics need a land ethic? Med Health Care Philos 2019;22(4):531-43.

19 Annas J. Intelligent virtue. Oxford, New York: Oxford University Press, 2011.

20 NHS Sustainable Development Unit. Carbon footprint update for the NHS in England 2015. NHS Sustainable Development Unit, 2016.

21 Syed SB, Dadwal V, Rutter P, et al. Developed-developing country partnerships: benefits to developed countries? Global Health 2012;8:17.

22 Whyte K. How similar are Indigenous North American and Leopoldian environmental ethics? Rochester, NY: Social Science Research Network, 2015.

23 Kimmerer RW. Braiding Sweetgrass: Indigenous wisdom, scientific knowledge and the Teachings of plants. SI: Penguin, 2020.

24 Fayemi AK, Macaulay-Adeyelure OC. Decolonizing bioethics in Africa. BEOnline 2016;3(4):68-90.

25 Lokugamage AU, Ahillan Tathberiya SDC. Decolonising ideas of healing in medical education. J Med Ethics 2020;46(4):265-72. 